\title{
AVANÇOSE DESAFIOS DA FORMAÇÃO PROFISSIONAL E TECNOLÓGICA EM UMA CRISE GLOBAL
}

A crise econômica e financeira mundial tem provocado um crescimento recorde de desemprego entre os jovens. As conseqüências sociais deste cenário são tão preocupantes que a Organização das Nações Unidas (ONU) instituiu 2010 como o Ano Internacional da Juventude e a Organização Internacional do Trabalho (OIT) acrescentou um alerta: "Mais de 80 milhões de jovens entre 15 e 24 anos estavam desempregados ao final de 2009. [...] A taxa de desemprego juvenil atingiu seu maior nível já registrado e deverá aumentar" (ORGANIZAÇÃO INTERNACIONAL DO TRABALHO, 2010).

Nessa conjuntura global - talvez a mais desfavorável desde a grande crise de 1929 -, dentre os jovens economicamente ativos, 13\% estão apartados de uma vida digna pois se encontram excluídos do mercado de trabalho. Já entre aqueles que obtiveram um emprego, 28\% (ou seja, um contigente de 152 milhões de jovens trabalhadores) estão em situação de extrema pobreza, vivendo em famílias que sobrevivem com menos de US $\$ 1,25$ por pessoa por dia.

Portanto, com a intensificação do desemprego e dos riscos associados à inatividade prolongada, ao subemprego, aos empregos informais e à pobreza, é fundamental a ampliação dos debates sobre Trabalho e Educação. Com esse intuito, Linhas Críticas apresenta o dossiê Formação Profissional e Tecnológica, reunido pela editora convidada Olgamir Francisco de Carvalho.

Então, este número 30 publica oito artigos científicos, uma atualidade, uma homenagem, as normas para publicação e um índice remissivo dos 339 autores que veicularam seus trabalhos desde o primeiro fascículo do periódico.

Assim, inicialmente, Richard Gagnon situa as especialidades técnicas enfocadas pela formação profissional e explora seus limites epistemológicos. Para tanto, analisa as divergências fundamentais entre conceitos de tradição (corpo) e tecnociência (mente), sendo o primeiro considerado concreto, temporal, espacial e o último, abstrato, amoral, mortal.

No artigo seguinte, Silvia Maria Manfredi retoma as políticas inclusivas de certificação profissional do Ministério do Trabalho e Emprego (2003 a 2007), as quais foram um contraponto significativo às orientações hegemônicas, e, de acordo com a autora, ainda necessitam ser ampliadas em prol da qualificação social de jovens e adultos.

Visando contribuir para a reflexão a respeito das políticas públicas em implantação no Brasil, Olgamir Francisco de Carvalho e Bernardo Kipnis examinam conceitos e experiências de reforma dos sistemas de educação profissional e tecnológica na Austrália, Canadá, Coreia do Sul e Portugal. 
Os Institutos Federais de Educação, Ciência e Tecnologia, criados em 2008, são analisados por Eliezer Moreira Pacheco, Luiz Augusto Caldas Pereira e Moisés Domingos Sobrinho, que abordam os aspectos históricos, políticos, curriculares, assim como sua contribuição para o fortalecimento da cidadania.

Lucília Regina de Souza Machado desvela as razões e as implicações enfatizadas pelo Ministério da Educação e pelo Conselho Nacional de Educação para a alteração da organização da oferta da educação profissional e tecnológica, que deixou de ser apresentada por áreas profissionais e passou a ser configurada por eixos tecnológicos.

Partindo dos dados do Censo Escolar, Remi Castioni e Maria Célia Costa Andrade discutem o impacto do ensino médio integrado à educação profissional. Analisam, também, se as mudanças no marco legal foram seguidas de uma efetiva ampliação da oferta de vagas pelas redes federal, estadual e privada.

Anita Handfas propõe uma leitura crítica das investigações submetidas ao grupo Trabalho e Educação da Anped. Tomando por base teórica Marx e Althusser, argumenta que esses estudos não avançaram em direção aos fundamentos do materialismo histórico.

Os aspectos teóricos e as contradições inerentes à formação do trabalhador, no movimento da economia solidária, são abordados por Ronalda Barreto Silva e Alessandra Bandeira Antunes Azevedo, privilegiando a reflexão sobre autogestão, cidadania e emancipação em situação de vulnerabilidade social.

Martha Pacheco, ao divulgar os Objetivos de Desenvolvimento do Milênio, propostos pela OIT, destaca o compromisso de trabalho digno e diálogo social expressos na Carta de Brasília (2009) e dá ênfase às metas do Centro Interamericano para el Desarrollo del Conocimiento en la Formación Profesional (Cinterfor).

Concluindo este número, compartilho o discurso proferido por Ilma Passos Alencastro Veiga por ocasião da cerimônia de outorga de seu Título de Professora Emérita, no dia 15 de março de 2010. Cabe explicitar que, ao longo dos 44 anos da Faculdade de Educação da Universidade de Brasília, essa foi a primeira homenagem de tamanha relevância acadêmica prestada a um dos nossos docentes.

Por fim, comemorando 15 anos ininterruptos, Linhas Críticas passa a circular com novo formato, layout e capa, frutos da arte de Edson Fogaça, e uma aprimorada diagramação, recriada por Paulo Selveira, ambos dedicados colaboradores da equipe Unesco de Brasília.

Antônio Villar Marques de Sá

\section{Referência}

Editor

ORGANIZAÇÃO INTERNACIONAL DO TRABALHO. Tendências globais de emprego para a juventude -2010. Disponível em: <http:/ / www.oitbrasil.org.br>. Acesso em: 17 set. 2010. 